\title{
Attitudes and Perceptions of Intimate Partner Violence in a Conservative Christian Church in Nigeria
}

\author{
Evans Nwachukwu Nwaomah \\ Department of Religious Studies, School of Education and Humanities, \\ Babcock University, Ilishan Remo, Ogun State, Nigeria
}

\begin{abstract}
This study examined attitude and perceptions of intimate partner violence (IPV) in a conservative Christian Church in Nigeria. The study utilizing anonymous survey methodology sampled 377 participants attending Seventh Day Adventist Church in Port Harcourt area of Rivers State, Nigeria. Findings from this study indicate intimate partner violence is wide spread in this population. The results show a significant relationship exist between, men's perceived right to control their wives' behaviour by force and justify such behaviour as culturally acceptable. The results therefore, indicate the need for family life education. The clergy and laity and those in the helping professions, community leaders and non-governmental organizations would need to device strategies towards putting an end to violence against women.
\end{abstract}

Keywords: Attitude, Perception, Women, Violence, Culture, Counselling.

DOI: $10.7176 /$ RHSS/9-10-04

Publication date:May $31^{\text {st }} 2019$

\subsection{Introduction}

Intimate partner violence (IPV) against women, otherwise referred to as wife beating, seems a growing social problem in Nigeria and in Sub-Saharan Africa. Women have been disfigured for life as a result of physical abuse which is perceived as sign of love. Such abuse is considered a private matter that must be kept secret within the confines of the family (Akolisa, 2002; Afronews, 2008; Coker-Appiah, and Cusack, 1999). Efforts aimed at eliminating such violence have always met with cultural resistance especially when placed against issues that confront the society today. Nevertheless, women abuse has emerged as one of the most widespread and frightening problems all over the world because of its incredible damage to its victim. Empirical and Anecdotal evidences suggest the perception of women abuse as cultural norm, permeates the length and breathe of SubSaharan Africa

(Adegoke \& Oladdeji, 2008; Adeyemi, et al., 2008; Aderinto, 2004; Ofei-Aboagye, 1994). This is a major source of concern as the attitude of wife beating is also noticed amongst couples in Christian population (Ndugasa, Okemgbo and Odimegwu, 2002, Narson-Clark, 2009; Fortune, 2011). Studies indicate a high prevalence of wife abuse exist in Nigeria and in Sub-Saharan Africa (Djamba and Kimuna, 2008; Nigeria National Population Commission, 2004; WHO, 2002). Despite its horrible consequences Fidgen, (2009) and Osei-Tutu, Mabel and Ernest (2017) opine that the practice of wife beating in the African worldview is an accepted way of keeping wives under control. Therefore, an important trigger for wife beating in traditional African society, is the transgression of established gender roles (Ogunjuyigbe, Akinlo, and Ebigbola, 2005; Omorogbe, Obetoh and Odion, 2010). Such transgression according to Baloyi (2013) include but not limited to "poor preparation of food for the husband and family, Lack of care for children, not seeking husband's permission to visit friends, and arguing with a husband." (p.713).

In the Eastern part of Nigeria, it seems women perceive wife beating as cultural norm and they argue that such reprimands, beating and occasional quarrelling are normal and healthy in marital relationships hence, they do not approve reporting such matters to the police or divorce their husbands but prefer reporting such cases to family members and pastors (Ilika, 2005). Similarly, a study in Zimbabwe on women abuse show that over 50\% of women believed that wife beating was justified under circumstances such as a wife arguing with her husband, neglect of her children, or going out without a husband's permission (Hindin, 2003). In Egypt, about eighty percent $(80 \%)$ of women justified wife beating on the grounds of a wife's' refusal to have sex with her husband (Thurston, Patten, and Lagendyk, 2006). Studies also show that acceptance of wife-beating was higher among women who had experienced trauma in childhood (World Health Organization, 2005; 2010). While both men and women are culprits of domestic abuse, studies indicate that women, especially in the rural communities, are most likely the target of spouse abuse in marital relationships for lack of social capital (World Bank, 1996).

In Nigeria, the attitude and perception of violence against women is predicated on culture and traditional norms of the people. From a traditional point of view, it appears men assume that wife beating is part of their marital rights and privileges guaranteed by the payment of bride price. Annon, (2007) commented on an ordeal of a man who was arrested by the police and locked up in police cell for beating his wife. The man lamented, "Why am I arrested for beating my own wife?" (p. 10). The desperate cry from this man, who did not understand the reason why he was arrested, comes from an understanding that a wife is bought just as any other chattel 
which belongs to the husband.

Furthermore, Waruta and Kinothi (2000) also observe that men agree that their wives belong to them just as their "shoes, cars, or other properties" (p.123). Unfortunately too, the women, mostly in the developing countries of the world, accept that label as justifiable traditional reasons for the beating they endure in their marriage. Women in this type of marital stress are voiceless and looked upon as slaves in their matrimonial homes. This type of attitude is not representative of a God who instituted marriage and the family and gave man a wife as a suitable partner "Help meet" to complement the man.

The issue of IPV/DV is not peculiar to Nigeria and Africa but occurs in both developed and developing countries of the world (Awoyemi, 2005; Antinmo, 2000; Dalal, Rahman, and Jansson, 2009) and cuts across societal structures regardless of age, fame, economic status, geographical locations and religious bias. IPV/DV can occur at any time even in a loving relationship. In Africa, one of the many social dimensions of women abuse is that husbands are adjudged to have exclusive rights to the wife (Antai, 2011; Alhmadi 2016). UNECA, (2010) argue that women's subordinate status to men in such cases, coupled with the general acceptance of interpersonal violence as a means of resolving conflict, renders women disproportionately vulnerable to violence from all levels of society. In the United States of America, studies show that approximately $20 \%$ of all nonfatal violence towards women is committed by men while only $3 \%$ of all nonfatal violence against men is committed by women (U.S. Department of Justice, 2003). Researchers estimate that between sixty-four to eighty-five percent $(64 \%$ to $85 \%)$ of intimate partner violence victims are women compared to $15 \%$ to $24.8 \%$ who are male victims (Tjaden, \& Thonnes, 2000; U.S. Department of Justice, 2000). Statistics also show that nearly one in every three adult women experiences at least one physical assault by a partner during adulthood (Heise, et al., 1999; United States Department of Health and Human Services: Center for Disease Control and Prevention, 2007).

\subsection{Demographics and Background Variables}

The demographic and background variables measured in this study in relationship to victimization were:

1. Sex

2. Age measured by a set of dummy variable related to the age groups $(18-25 ; 26-35 ; 36-45 ; 46-55$; $56-65 ; 66-75 ; 76-85 ; 85+)$.

3. Marital status as measured by a set of dummy variable related to each of the six marital status groups (Single, Married, Separated, Divorced, Widowed, with Partner (husband/wife

4. A divorced separate dummy variable $(1=$ divorced or separated, $0=$ Not divorced or separated $)$

5. Family economics (Very difficult and stressful; difficult, but manageable; adequate; better than average; very comfortable)

6. Education level

7. Spouse education level

8. Church attendance (once per year or less including never; Several times per year; One to three times per month; at least once per week)

9. Practice church doctrine (Very conservative; Closely or traditionally; Conservatively; Liberally; Interpret doctrines more non- traditionally; non practicing)

10. Ethnicity was measured by a set of dummy variable related to each of these groups (Ikwere, kalagbari, Ekpeye, Abua, Degema, Ogba, Igbo Andoni, Yoruba, Hausa, Ogoni, Ijaw, Okirika, Cross River and other). 
Vol.9, No.10, 2019

Table 1 Demographics

\begin{tabular}{|c|c|c|c|c|}
\hline & TYPE & $\%$ & TYPE & $\%$ \\
\hline Sex & Male & $49 \%$ & Female & $51 \%$ \\
\hline \multirow[t]{3}{*}{ Age } & $18-35$ & $30 \%$ & $56-75$ & $13 \%$ \\
\hline & $36-45$ & $33 \%$ & $75+$ & $0 \%$ \\
\hline & $46-55$ & $27 \%$ & & \\
\hline \multirow[t]{3}{*}{ Marital Status } & Married & $65 \%$ & Single/Never Married & $12 \%$ \\
\hline & Separated/Divorced & $4 \%$ & Widowed & $1 \%$ \\
\hline & Living with a Partner & $18 \%$ & & \\
\hline \multirow[t]{2}{*}{ Marriage } & $1^{\text {st }}$ & $91 \%$ & $3 \mathrm{rd}+$ & $5 \%$ \\
\hline & $2^{\text {nd }}$ & $4 \%$ & & \\
\hline \multirow[t]{2}{*}{ Divorces } & 1 & $66 \%$ & $3+$ & $9 \%$ \\
\hline & 2 & $25 \%$ & & \\
\hline \multirow[t]{2}{*}{ Education } & Primary school or less & $7 \%$ & University graduate & $62 \%$ \\
\hline & Secondary School & $31 \%$ & & \\
\hline \multirow[t]{2}{*}{ Spouse Education } & Primary school or less & $4 \%$ & University graduate & $61 \%$ \\
\hline & Secondary School & $35 \%$ & & \\
\hline \multirow[t]{3}{*}{ Income } & None & $19 \%$ & N301,000-N500,000 & $17 \%$ \\
\hline & N120,000-N150,000 & $23 \%$ & N501,000-N1,000,000 & $18 \%$ \\
\hline & N151,000-N300,000 & $19 \%$ & $\mathrm{~N} 101,000,000+$ & $5 \%$ \\
\hline \multirow[t]{2}{*}{ Economic Situation } & Very difficult/Stressful & $15 \%$ & Difficult, but manageable & $44 \%$ \\
\hline & Better than Average & $31 \%$ & Very comfortable/Adequate & $11 \%$ \\
\hline \multirow[t]{2}{*}{ Church Attendance } & Once per year or less & $2 \%$ & $1-3$ times a month & $6 \%$ \\
\hline & Several times per year & $50 \%$ & At least once a week & $43 \%$ \\
\hline \multirow[t]{2}{*}{ Church Affiliation } & Baptized SDA & $92 \%$ & Attending SDA & $7 \%$ \\
\hline & Catholic & $1 \%$ & No particular beliefs & $0 \%$ \\
\hline \multirow[t]{2}{*}{ Practice Church Doctrines } & Very conservatively & $17 \%$ & Liberally & $24 \%$ \\
\hline & Conservatively & $58 \%$ & Non-practicing & $1 \%$ \\
\hline \multirow[t]{3}{*}{ Ethnicity } & Ikwere/Kalagbari & $7 \%$ & Ekpeye/Abua/Degema & $32 \%$ \\
\hline & Ogba & $5 \%$ & Igbo & $21 \%$ \\
\hline & $\begin{array}{l}\text { Andoni/Yoruba/Hausa } \\
\text { /Cross River }\end{array}$ & $13 \%$ & $\begin{array}{l}\text { Ogoni/Ijaw/Okirika } \\
\text { /Other }\end{array}$ & $22 \%$ \\
\hline
\end{tabular}

\subsection{Data Analysis}

Port Harcourt is an ethnically diverse community. The ethnic composition, language and culture in Port Harcourt area also differ from each other. The sample size for this study comprised of $53 \%$ women and $47 \%$ of men and had a wide range of age distribution. A similar distribution is also seen from the economic situation of the family. Analysis show that most of the families measured in this study were slightly living above poverty. The result of this study show intimate partner violence cuts across social class and boundaries and it is a serious problem among couples in the Seventh Day Adventist Church in Nigeria showing no signs of abating, as silence on abuse against women still pervade our society (Nason-Clark, 2004; Fortune, 1991; Potter, 2007). This study which explored the attitudes and perception of intimate partner abuse in a conservative Christian Church in Nigeria, is similar to the findings of Drumm et al., (2006) in North America area of the US; and Nason-Clark (2009) in Atlantic Canada. Their findings validates the result of this study which shows the prevalence of domestic abuse within Christian congregations. Results reveal substantial divergent opinions among participants regarding reasons for partner abuse. The summary of attitude and perceptions is presented in the table below.

\subsection{Methodology}

This study investigated the attitude and perceptions of intimate partner violence (IPV) in conservative Christian Church in Nigeria. The study utilizing anonymous survey methodology sampled 377 participants attending some Seventh-Day Adventist Churches in Port Harcourt area of Rivers State, Nigeria. This exploratory study utilized survey questionnaires and asked the following questions.

\subsection{Research Questions}

1. What is the prevalence of intimate partner physical violence in this population?

2. What are the views and attitudes of this population about IPV and do they vary by gender?

3. What types of attitudes and personal characteristics are related to intimate partner physical victimization? 
Table 2. Physical Violence Victimization by Sex

Lifetime Occurrence with an Intimate Partner

Threatened to hit or throw something at you

Threw, smashed, hit, or kicked something to frighten you

Pushed, grabbed, or shoved you

Beat you up mercilessly

Threatened to kill you if ever challenged him/her

Independent t-tests revealed significant differences on each item

$26 \%$ of the sample said that one of these had happened with an intimate partner in his/her lifetime

Table 3. Religious Attitudes toward Intimate Partner Violence by Sex

\begin{tabular}{|c|c|c|}
\hline $\begin{array}{l}\text { Opinions and Attitudes } \\
\text { Percent Agree or Strongly Agree }\end{array}$ & Male & Female \\
\hline Domestic abuse is a serious problem in the Adventist church. & $76 \%$ & $75 \%$ \\
\hline $\begin{array}{l}\text { If a woman summits to her husband as God desires, God will eventually honor her and either } \\
\text { the abuse will stop or God will give her the strength to endure. }\end{array}$ & $88 \%$ & $70 \%$ \\
\hline The severity of domestic abuse has been exaggerated by the "women's movement." & $58 \%$ & $39 \%$ \\
\hline If the couple goes for counseling, the abuse will likely stop. & $81 \%$ & $66 \%$ \\
\hline Many men use violence against women to gain power and control. & $36 \%$ & $72 \%$ \\
\hline Abuse only occurs if physical violence happens. & $44 \%$ & $34 \%$ \\
\hline Emotional abuse can be just as harmful as physical abuse. & $85 \%$ & $82 \%$ \\
\hline
\end{tabular}

An independent-samples t-test was conducted to identify significant differences between male and female attitudes about IPV. Three items revealed significantly different mean scores on three attitude variables:

1. If a woman summits to her husband as God desires, God will eventually honor her and either the abuse will stop or God will give her the strength to endure.

2. The severity of domestic abuse has been exaggerated by the "women's movement."

3. Many men use violence against women to gain power and control.

Table 4. T-test on Male/Female Attitude Differences on IPV

\begin{tabular}{|c|c|c|c|c|c|c|}
\hline Attitudes about IPV & Sex & $\mathbf{N}$ & $\mathbf{M}$ & SD & $t$ & $p$ \\
\hline \multirow{2}{*}{$\begin{array}{l}\text { If a woman summits to her husband as God desires, God will } \\
\text { eventually honor her and either the abuse will stop or God will } \\
\text { give her the strength to endure. }\end{array}$} & Male & 178 & 1.76 & 1.021 & \multirow[t]{2}{*}{$\overline{-}-741$} & \multirow[t]{2}{*}{.006} \\
\hline & Fen & 181 & 2.09 & 1.281 & & \\
\hline \multirow{2}{*}{$\begin{array}{l}\text { The severity of domestic abuse has been exaggerated by the } \\
\text { "women's movement." }\end{array}$} & Male & 177 & 2.52 & 1.088 & \multirow{2}{*}{-} & \multirow[t]{2}{*}{.000} \\
\hline & Femal & 168 & 2.95 & 1.136 & & \\
\hline \multirow{2}{*}{$\begin{array}{l}\text { Many men use violence against women to gain power and } \\
\text { control. }\end{array}$} & Male & 179 & 3.03 & 1.106 & \multirow[t]{2}{*}{7.076} & \multirow[t]{2}{*}{.000} \\
\hline & Female & 171 & 2.24 & .986 & & \\
\hline
\end{tabular}

Table 5. Stepwise Multiple Regression Results for Religious Attitudes

\begin{tabular}{lccccc}
\hline Variable & $\begin{array}{l}\text { Regression } \\
\text { Estimator (B) }\end{array}$ & $\begin{array}{c}\text { Standard } \\
\text { Error of B }\end{array}$ & $\begin{array}{c}\text { Standard } \\
\text { value of } \boldsymbol{\beta}\end{array}$ & t-statistic & P of t \\
\hline (Constant) & 6.291 & .463 & & 13.593 & .000 \\
Sex (Female) & 1.023 & .244 & .301 & 4.200 & .000 \\
Attitude: Couples Counseling & .333 & .121 & .201 & 2.756 & .007 \\
Attitude: Submission & .258 & .111 & .170 & 2.323 & .021 \\
\hline
\end{tabular}

$\begin{array}{cc}R^{2} & =1.79 \\ \text { Adjusted } R^{2} & =.164\end{array}$

$\mathrm{F}$ value for model $=11.728$

Not significant:

Sex

Age

Your education level

Income

Family economic picture

Church attendance

Practice the doctrines of your church

Age 
Education

Income

Family economic picture

Church attendance

Practice the doctrines of your church

Domestic abuse is a serious problem in the Adventist church

The severity of domestic abuse has been exaggerated by the "women's movement"

Men use violence against women to gain power and control

Abuse only occurs if physical violence happens

Emotional abuse can be just as harmful as physical abuse

The multiple stepwise regression analysis indicates that three factors are independently and significantly related to physical victimization by an intimate partner. Females were more likely to have experienced physical victimization than men in this sample. Victims of physical violence were also more likely to disagree with the following statements that:

1. If the couple goes for counseling, the abuse will likely stop.

2. If a woman summits to her husband as God desires, God will eventually honor her and either the abuse will stop or God will give her the strength to endure.

Therefore, there is some support that when women experience physical violence by an intimate partner, they gain insights into the realities of the domestic violence dynamic. First that neither couples counseling or submitting to their husbands is the answer to stopping abuse. There are cases where women who submit to their husband's authority were still abused and some killed in the process. We argue here that submission to spousal authority must emanate out of love (Eph.5:22-25). The scripture which enjoins wives to be submissive to their husbands (Ehp 5:22-25), also admonishes husbands to love their wives even as Christ loved the Church and gave himself for it. The wife is to submit to the husband as to the Lord and the husband is to see that he cherishes and nurtures his wife in love. It appears St Paul's admonition in this passage is aimed at balancing the relationship that exist between a husband and his wife and to avoid bitterness and rancor in their relationship. This is a willful action that requires intelligent decision as the wife willingly submits herself to her husband. Christian women do not submit to the Lord out of resentment but out of love. And it is this type of submission that wives are exhorted to show to their husbands, and husbands are required to honour and reciprocate this gesture to their wives by showering them with love, respect and honour

\subsection{Biblical response to husband and wife submission}

Biblical scholars and social science researchers (Heil, 2007; Kroeger, 1995; George E Ladd, 1993; Nason-Clark, 1997), argue that submission in marriage is a mutual relationship which exists between a man and his wife with mutual respect for each other. Paul in Eph. 5:21 argue that it is the duty of husband and wife to submit to one another out of reverence for Christ. Often the verses following Ephesians 5:21 are taken out of context in order to demand a unilateral submission of the wife to her husband. Such a position comes from centuries of patriarchal (male) dominated culture. For example, Aristotle, cited in (Hoehner, 2002) says that "The rule of a household is a monarchy, for every house is under a head" (p. 140). Following Aristotle's idea many Greeks and Roman authors wrote about a household management code basing their argument on the principle of male monarchy. The patriarchal norms of the Greco-Roman world, built into the rules and regulations for everyday life and relationships, demanded wifely submission to the authority and headship of the husband (Brauch, 1996). Because of such cultural bias, many Christian commentators and teachers then perpetuated the teaching that a wife is to unilaterally submit to her husband. This appears to be a diversion from what is stated in Eph 5:21, where the first half of the sentence is ignored and the second half of the sentence in 5:22 is abused. Submission, according to the text, is made to one another. Ellen G. White, (1952) comments that:

The Lord Jesus has not been correctly represented in His relation to the church by many husbands in their relation to their wives, for they do not keep the way of the Lord. They declare that their wives must be subject to them in everything. But it was not the design of God that the husband should have control, as head of the house, when he himself does not submit to Christ. He must be under the rule of Christ that he may represent the relation of Christ to the church. If he is a coarse, rough, boisterous, egotistical, harsh, and overbearing man, let him never utter the word that the husband is the head of the wife, and that she must submit to him in everything; for he is not the Lord, he is not the husband in the true significance of the term. . Husbands should study the pattern and seek to know what is meant by the symbol presented in Ephesians 5. The husband is to be as a Saviour in his family. .. Let every husband and father study to understand the words of Christ, not in a one-sided manner, merely dwelling upon the subjection of the wife to her husband, but in the light of the cross of Calvary, study as to his own position in the family circle. "Husbands, love your wives, even as Christ also loved the church, and gave Himself for it; that He might sanctify and cleanse it with the washing of water by the word." (pp. 
117-118).

In the Greek text the word (u potasso) meaning "to submit", is been used in a sense which refers to an equal placing of oneself in subjection to another for the benefit of all concerned. It means literally placing the needs of others higher than your own. This form of submission is not unilaterally applied. Such submission is to one another. Just as the wife is called to place her husband's needs above her own, the husband is also called to place his wife's needs above his own. While we are not advocating for women's civil disobedience, it is sensible to state here that such obedience and submission, must be done intelligently.

\subsection{Conclusion}

This study provides the insight that shape the perception of perpetration of domestic violence amongst couples in the Seventh Day Adventist Church. The study demonstrates that domestic violence is a global problem that is present not only in the secular domain, but also among Christian population (Nason-Clark, 2009). The Church continuous to witness a growing number of broken families, and orphans and widows continue to increase in our congregations as a result of women abuse. Baloyi (2009) argue that wife beating like any other form of abuse traumatizes women and render them incapable of functioning optimally in their families and in the wider society. Our theology, therefore, must relate the message of freedom (Luke 4:16-18) to the situation of the oppressed in the family and the society. The clergy as a shepherd must not shy away from addressing the problem of abuse in the congregation. It is from this perspective that we see the relevance of the pastoral call. The way that Jesus came down to our level to relate to and socialized with drunkards, outcasts, prostitutes and thieves as a way to liberate and save them, should similarly be the intention of the church and pastoral involvement. The clergy and the helping profession in the congregation should be involved in helping and liberating women from the shackles of harmful traditional culture that demean and reduce the capacity of women. The results from this study highlight the fact that clergy will play important roles in the prevention of abuse in families. Anecdotal evidences and my experiences in the mission field as a gospel minister in Africa, suggest that clergy has been less vocal with conflicting views on how to handle domestic abuse among couples. The indicators in this study point to the challenges of educating families on violence prevention. Decreasing domestic violence in intimate partner relationship requires a change of attitude towards the other person and valuing the personhood of women as the image of God. While it is not unusual for partners to experience some form of difficulties in relationships, it is vitally important to seek ways to resolve such difficulties through healthy dialogue, counseling and personal development. The old saying, "an ounce of prevention is worth a pound of cure" (author unknown) is very true in situations involving abuse. The deep emotional pain and the devastations left in the wake of an abusive incident leaves scars that last for a long time and destroys relationships. Rather than dealing with the aftermath of abuse, it would be helpful to stop the abuse before it starts.

\subsection{Recommendations}

Findings of this study indicate that attitude is a key variable that shapes violence against women. Although violence against women has cultural, undertone, its principle actor appear to be men's attitude on violence against women. Therefore, efforts to prevent spousal abuse in relationships, especially against women, must address not only those attitudes that are overtly condoning of violence against women but also the wider clusters of attitudes related to gender and sexuality that normalize and justify this violence. Similarly, intervention and prevention efforts must address particularly social processes and settings through which violence-supportive attitudes are maintained. Fundamental processes include the intergenerational transmission of violence. Cultural norms that demean and subjugate women as second class citizens, by denying them their rights, be abandoned for an egalitarian type of relationships where both men and women can exercise their rights and privileges as equal partners in marital relationship.

The Church should continue to educate and create awareness of domestic abuse amongst couples in relationships. This awareness campaign would help to showcase the consequences of gender-based violence and thus stem the tide of violence amongst intimate partners.

There is the need for proactive efforts in faith communities to break the cultural norms and practices that sustain women's susceptibility to abuse in the society. This can be done through dialogue, seminars and workshops to address the dangers of IPV/DV. This study points to the need of policy and program implementations in our congregations that would help decrease abuse in Christian homes and communities. A concerted effort of the clergy and the laity is therefore necessary to raise awareness against the attitude of wife beating which is regarded as being normal in marital relationships. On the other hand, women must stop patronizing the acceptance and tolerance of wife-beating as a cultural norm. The idea of accepting anything goes in marital relationships is counterproductive and injurious to personal health and wellness. This attitude reduces the integrity of women and encourages the social and cultural norms that subjugates women in the society thus undermining women's worth and self-esteem. Wife-beating is alien in God's scheme of things with regards to husband and wife relationship. Reducing the prevalence of wife-beating requires men and women's positive 
attitude of being liberated from the blinding cultural stereotypical norms of the society through the power of the gospel. The scripture says if the son shall make you free, ye are free indeed (John 8:36). The perpetration of wife/husband abuse and the acceptance of such attitudes as normal may be an indication of a deeper problem in the husband and wife relationship which is suggestive of an inter-personal conflict that is barely addressed in such relationships. There is the need for pre-marital and post-marital counseling in relationships. This is necessary to avert the dangers of abuse in relationships.

\section{REFERENCES.}

Adegoke, T. G., \& Oladdeji, D. (2008). Community norms and cultural attitudes and Beliefs factors influencing violence against women of reproductive age in Nigeria. European Journal of Scientific Research, 20(2), 265-273.

Aderinto, A. A. (2004). Domestic violence among the middle class in Edo and Delta States. In I M Thomas, L E Erinosho \& F Orenuga (Eds.), Domestic violence among middle class Nigerians (pp. 52-69). Lagos: Inter African Committee.

Adeyemi, A., Irinoye, O., Oladimeji, B., Fatusi, A., Fatoye, F., Mosaku, S., et al. (2008). Preparedness for Management and Prevention of Violence Against Women by Nigerian Health Professionals. Journal of Family Violence, 23(8), 719-725.

Afronews. (2008). Nigeria: half of women experience domestic violence. Off Our Backs, 35(5/6), 5-5. Retrieved from http://www.afronews.com/articles/16471 cited on 22 May 2010

Aimakwu, C. O., Olayemi, O., Iwe, C. A. B., Oluyemi, F. A., Ojoko, I. E., Shoretire, K. A., et al. (2004). Current causes and management of violence against women in Nigeria. Journal of Obstetrics and Gynaecology, 24(1), 58-63.

Akolisa, U. (2002). Please let us say that you are our husband. The Comet, Lagos Nigeria, p. 19.

Anon, 2007, 'Where am I wrong when I beat my wife', City Press, 18 February, p. 10.

Anon, 2013, 'Woman heavily beaten for refusing to have sex with hubby', in My Zimbabwe, viewed 14 August 2013, from www.myzimbabwe.co.zw/news/5741- woman-heavily-beaten-for-refusing-to-have-sex-withhubby.html

Antai, D. (2011). Controlling behavior, power relations within intimate relationships and intimate partner physical and sexual violence against women in Nigeria. Antai BMC Public Health, 11(511), 1-2.

Atinmo, M. (2000). Sociocultural implications of wife beating among the Yoruba. In K. Oyekanmi (Ed.), Men, Women and violence. Ibadan, Nigeria: University Press Ibadan.

Awoyemi, G. (2005). Man butchers wife in Lagos. Nigerian Tribune 12 May, Ibadan, p. 3.

Baloyi, M.E (2013). Wife beating Amongst Africans as a challenge to Pastoral Care. Indie Luce Verbi 47(1) P.713 http://dx.doi.org/10.4102/ids.v47i1.713

Coker-Appiah, D., \& Cusack, K. (1999). Violence against women and children in Ghana: Breaking the silence, challenging the myths and building support. Accra: Gender Studies and Human Rights Centre.

Coker, A. L., \& Richter, D. L. (1998). Violence against women in Sierra Leone: Frequency and correlates of intimate partner violence and forced sexual intercourse. African Journal of Reproductive Health, 2(1), 6172.

Dalal, K., Rahman, F. and Jansson, B. (2009) 'Wife abuse in Rural Bangladesh`. Journal of Biosocial Science, Vol. 41(5):561-573.

Djamba, Y. K., \& Kimuna, S. R. (2008). Intimate Partner Violence among Married Women in Kenya. Journal of Asian \& African Studies (Sage Publications, Ltd.), 43(4), 457-469.

Drumm, R., Popescu, M., McBride, D., Hopkins, G., Thayer, J., Wrenn, J., et al. (2006). Intimate partner violence in a conservative Christian denomination. Social Work \& Christianity, 33, 233-252.

Fidgen, J., 2009, Zambia's celebrity couple reveal wife-beating past, cited on 9 July 2015 from http://news.bbc.co.uk/2/hi/africa/8375291.stma

Fortune, M. M. (2001). Religious issues and violence against women. In C. M. Renzetti, J. L. Edleson \& R. K. Bergen (Eds.), Sourcebook on violence against women (pp. 371-385). Thousand Oaks, CA: Sage Publications.

Heise, L., Ellsberg, M., \& Gottemoeller, M. (1999). Ending Violence Against Women. Population Reports. Baltimore, : John Hopkins Univeristy School of Public Health.

Heise, L. L., Raikes, A., Watts, C. H., \& Zwi, A. B. (1994). Violence against women: a neglected public health issue in less developed countries. Soc Sci Med, 39(9), 1165-1179.

Kwawukume, E. Y., \& Kwawukume, S. B. (2001). Violence against pregnant women: the patients perspective. Nigerian Journal of Clinical Practice, 4, 76-79.

Nason-Clark, N. (1997). The battered wife: How christians confront family violence. Louisville, Kentucky: Westminister John Knox press.

Nason-Clark, N. (2009). Christianity and the experience of domestic violence:What does faith have to do with it? 
Social Work \& Christianity, 36(4), 379-393.

Ndugasa, C., Okemgbo, A. K., \& Odimegwu, C. O. (2002). Prevalence, Patterns and Correlates of Domestic Violence in Selected Igbo Communities of Imo State, Nigeria. Women's Health and Action Research Centre (WHARC), 6, 5-10.

Nienhuis, N. E. (2005). Theological reflections on violence and abuse. The Journal of PastoralCare and Counseling, 59(1-2), 109-123.

Nigeria National population commission. (2004). Nigeria demographic and health survey 2003, Lagos- Nigeria.

Odimegwu, C. O. (1997). The girl-child situation in south-eastern Nigeria. Final report submitted to the InterAfrican Committee on Harmful Traditional Practices Affecting Women and Children (IAC), Nigeria. Ile Ife: Inter African committee on harmful traditional practices.

Ofei-Aboagye, R. (1994). Domestic violence in Ghana: An initial step. Columbia Journal of Gender and Law, $4(1), 1-25$.

Ogunjuyigbe, p. O., Akinlo, A., \& Ebigbola, J. A. (2005). Violence against women: An examination of men's attitudes and perceptions about wife beating and contraceptive use. [Article]. Journal of Asian \& African Studies (Sage Publications, Ltd.), 40(3), 219-229.

Okemgbo, C. N. (2001). The socio-demographic and economic factors influencing violence against women in selected areas of Imo state, Nigeria. Obafemi Awolowo University, Ile-Ife.

Okemgbo, C. U. (1999). The social context of violence against women and Reproductive Health among married women in Imo state. Paper presented at the Postgraduate Seminar in the Department of Demography and Social Statistics, 15 August 1999. Obafemi Awolowo University, Ile-Ife Nigeria.

Okereke, G. O. (2002). Incidence of physical spouse abuse in Nigeria: A Pilot Study. Research Review, 39-51.

Omorogbe, S. K., Obetoh, G. I., \& Odion, W. F. (2010). Causes and Management of Domestic Conflicts among Couples: The Esan Case. Journal of social Science, 24(1), 57-63.

Osei-Tutu, Ellen Mabel and Ampadu, Ernest (2017). Domestic Violence against Women in Ghana: The Attitudes of Men toward Wife-Beating. Journal of International Women's Studies, $18(4), \quad 106-116$. Available at: http://vc.bridgew.edu/jiws/vol18/iss4/8

Speizer, I. S. (2010). Intimate Partner Violence Attitudes and Experience Among Women and Men in Uganda. Journal of Interpersonal Violence, 25(7), 1224-1241.

Straus, M. (1979). Measuring intrafamily conflict and violence: The conflict tactics (CT) scales. Journal of Marriage and the Family 41(1), 75-88.

Tjaden, P., \& Thonnes, N. (2000 ). Extent, nature, and consequences of intimate partner violence research report: Findings from the National Violence against Women Survey. US Department of Justice/Centers for Disease control and prevention, Washington D.C.

United States Department of Health and Human Services:Centers for Disease Control and Prevention. (2007). Intimate partner violence. from http://www.cdc.gov/ncipc/factsheets/ipvoverview.htm Retrieved on 25 August, 2010

US Department of Justice. (2000). Extent, nature, and consequences of intimate partner violence. Washington, DC.

Waruta, D.W. and Kinoti, H.K., 2000, Pastoral care in African Christianity, Acton Press, Nairobi.

WHO. (2002). World report on violence and health. Geneva: World Health Organization.

World Bank. (1996). Nigeria poverty in the midst of plenty, the challenge of growth with inclusion: A world Bank poverty Assessement Handbook.

World Health Organization/London School of Hygiene and Tropical Medicine. (2010). Preventing intimate partner and sexual violence against women: taking action and generating evidence. Geneva: World Health Organization.

White, Ellen Gold. (1952) Adventis Home, Hagerstown, MD: Review and Herald. 